\title{
SISTEM PENDUKUNG DALAM PEMBUATAN KEPUTUSAN KLINIS PERAWAT DI RUMAH SAKIT
}

\author{
Januarizkah Napitu \\ januarizkahnapitu@gmail.com
}

\begin{abstract}
LATAR BELAKANG
Perawat merupakan tenaga profesional yang bertanggung jawab dalam memberikan proses keperawatan kepada klien. Berdasarkan hal tersebut perawat harus mampu mengambil keputusan klinis sebagai upaya membantu pasien dalam memecahkan masalah dan menemukan jalan keluar dari setiap masalah keperawatan yang dialami pasien. Perawat selalu dihadapkan dengan berbagai masalah klinis dalam memberikan perawatan terhadap pasien. Perawat yang profesional tentu saja akan mampu mengambil keputusan klinis agar masalah pasien dapat diatasi dengan cepat dan tepat. Kurangnya kemampuanperawat dalam mengambil keputusan dalam situasi yang kritis tentu saja akan membahayakan pasien dan menimbulkan kerugian bagi pasien, diantaranya pasien akan terlambat untuk mendapatkan bantuan hidup, kondisi pasien akan semakin memburuk dan akibat yang paling fatal adalah kematian (Potter\& Perry, 2009). Tingginya angka kematian di perawatan intensif menuntut perawat untuk mengambil keputusan klinik dalam menghadapi berbagai masalah dan kasus kasus emergensi. Sesuai dengan penelitian yang dilakukan oleh Golnoosh Mirsaidi (2012) menunjukkan bahwa faktor individu yang berhubungan dengan pengambilan keputuan klinik adalah usia, jenis kelamin, latar belakang pekerjaan, unit kerja, lama kerja di unit dan status pekerjaan.
\end{abstract}

Sistim pendukung keputusan klinis ( CDSS ) adalah sistem teknologi informasi kesehatan yang dirancang untuk memberikan dokter dan profesional kesehatan lainnya dengan dukungan keputusan klinis ( CDS ), yaitu, bantuan dengan tugas - tugas pengambilan keputusan klinis(Ascp \& Robicsek, 2015 ; Wikipedia, 2009). Oleh karena itu maka tujuan penulis menyusun literature review ini adalah untuk mengetahui sistim pendukung keputusan klinis yang dapat mendukung pembuatan keputusan klinisoleh perawat bagi pelayanan pasien di rumah sakit. Perawat dalam mengidentifikasi dan merespons pasien yang memburuk terkadang membuat keputusan secara otonom, salah menafsirkan bukti, tanggapan yang terkondisi dan tidak melihat isyarat (Johansen \& Brien, 2015). Keputusan klinis yang dibuat 
perawat harus didukung dengan data yang akurat serta lengkap dan sistim yang baik agar dapat menjawab kebutuhan pasien secara tepat. Sistim pendukung keputusan klinis ( CDSS ) yang direncanakan dengan baik dan dimasukkan ke dalam layanan kesehatan akan menciptakan layanan yang berkualitas dan meningkatkan efektivitas serta mengurangi biaya perawatan (Parsania et al., 2017). Oleh karena itu maka tujuan penulis menyusun literature review ini adalah untuk mengetahui sistem pendukung keputusan klinis yang dapat mendukung pembuatan keputusan klinis oleh perawat bagi pelayanan pasien di rumah sakit.

\section{METODE}

Metode yang saya gunakan adalah metode literasi. Saya membaca beberapa sumber referensi berupa jurnal dan buku, kemudian mengidentifikasi pengambilan keputusan oleh perawat, faktor-faktor dalam pengambilan keputusan, dan sistem pendukung dalam pembuatan keputusan klinis perawat di rumah sakit.

\section{HASIL}

Pengembangan alat sebagi sistim informasi klinis pemberian obat dengan cara perawat diamati saat memberikan obat dalam lingkungan simulasi kemudian perawat berpartisipasi dalam kelompok fokus untuk memberikan masukan dan hasilnya perawat menunjukan kecenderungan untuk meremehkan kebutuhan akan dukungan(Moss \& Berner, 2015). Dalam menilai akurasi diagnostik sistim pendukung keputusan klinis pada pasien dengan sepsis dilakukan dengan dua tahap yaitu dukungan keputusan klinis berbasis cloud untuk mendeteksi pasien yang berisiko mengalami sepsis, sistim cloud menyampaikan pemberitahuan kepada perawat yang ditunjuk pasien yang secara elektronik menghubungi penyedia layanan. Kedua terdiri dari skrining sepsis dan formulir stratifikasi yang diintegrasikan ke dalam catatan kesehatan elektronik pasien, yang merupakan alat bantu pengambilan keputusan berbasis bukti, yang digunakan untuk menilai pasien di samping tempat tidur dan hasilnya bahwa sistim alarm biner pendukung keputusan klinis dengan fungsionalitas cross-checking meningkatkan pengenalan dini dan memfasilitasi stratifikasi pasien dengan sepsis(Amland, Lyons, Greene, \& Haley, 2015).

Sistim pendukung keputusan klinis (CDSS) yang dapat digunakan untuk mendukung keputusan klinis perawat adalah NEWS dan metode refleksi Tanner akan tetapi harus terlebih dahulu diuji coba dan disosialisasikan terkait manfaat serta cara penggunaannya kepada perawat, harus aman bagi pasien dan tidak merugikan pasien serta rumah sakit. Evaluasi 
terhadap efek dari penerapan metode refleksi Tanner hasilnya menunjukan bahwa penerapan metode refleksi Tanner dapat secara signifikan meningkatkan skor rata-rata dan tingkat pengambilan keputusan klinis perawat ICU(Razieh, Somayeh, \& Fariba, 2018)dan evaluasi terhadap pengalaman perawat dalam menggunakan National Early Warning Score (NEWS)hasilnya yaitu perawat melaporkan bahwa NEWS mudah digunakan, tidak menambah beban kerja dan meningkatkan kemampuan perawat untuk mengidentifikasi pasien yang memburuk(Fox, 2015). Dalam perawatan pasien di rumah sakit termasuk di ruangan ICU belum digunakan sistim pendukung keputusan klinis bagi perawat. Kedua sistim ini meskipun sudah digunakan oleh rumah sakit di negara lain namun apabila akan diadopsi penggunaannya di rumah sakit di Indonesia maka harus dipelajari dulu manfaat dan kekurangannya sebelum digunakan sehingga pada saat digunakan dapat mendukung keputusan klinis yang dibuat oleh perawat dan tidak merugikan pasien dan rumah sakit.

\section{PEMBAHASAN}

\section{A. Pengambilan keputusan oleh perawat}

Pengambilan keputusan yang baik dari perawat akan mendukung kualitas perawatan yang diberikan kepada pasien tetapi jika tidak didukung dengan pengetahuan dan keterampilan yang baik dari perawat dalam melakukan pengambilan keputusan klinik keperawatan maka akan menurunkan mutu dan kualitas dari proses keperawatan yang diberikan kepada pasien sehingga untuk mengatasi hal tersebut peneliti berpendapat perlu mengevaluasi kemampuan perawat untuk mengetahui sejauhmana pengetahuan dan keterampilan yang dimiliki perawat untuk dapat melaksanakan kerja dengan baik. Pembuatan keputusan klinik adalah hal yang sangat vital pada prak ? k keperawatan. Point dari pembuatan keputusan keperawatan harus memiliki dampak yang menyeluruh terhadap performa organisasi dan mampu memberikan dampak juga secara finansial. Memberikan kualitas dan pelayanan yang aman adalah tujuan dari seluruh organisasi pelayanan kesehatan.

Oleh karena itu pembuatan keputusan klinik yang efektif harus benar - benar dilaksanakan (Diane L, 2018).

\section{B. Fakor-faktor dalam pengambilan keputusan klinis}

Pengambilan keputusan klinik berhubungan dengan beberapa faktor diantaranya adalah: usia, pendidikan sertifikat yang dimiliki perawat, lama kerja di unit dan unit tempat perawat bekerja. Penelitian yang dilakukan oleh Golnoosh Mirsaidi pada tahun 2012 menunjukkan bahwa ada beberapa faktor yang berhubungan dengan pengambilan keputusan 
klinik diantaranya usia, jenis kelamin, latar belakang pekerjaan, unit kerja, lama kerja di unit dan status pekerjaan.

1. Usia

Usia merupakan indikator seseorang dalam mengambil keputusan klinik. Semakin bertambahnya umur seseorang maka akan membuat seseorang tersebut semakin bertanggung jawab dan berpengalaman. Hasil penelitian menunjukkan bahwa perawat yang melakukan pengambilan keputusan baik berumur lebih muda (32,10 tahun) dibandingkan perawat yang melakukan pengambilan keputusan tidak baik (34,79 tahun). menurut hasil penelitian yang dilakukan oleh Golnoosh Mirsaidi (2012) menunjukkan bahwa usia 46 - 50 tahun memiliki pengambilan keputusan yang maksimum dibandingkan dengan usia 26 - 30 tahun, hasil penelitian ini menunjukkan bahwa ada hubungan yang signifikan antara pengambilan keputusan klinik dengan usia perawat. Hasil penelitian dapat diketahui bahwa umur bukan merupakan faktormutlak seseorang bisa ber? ndak dan bekerja secara professional. Jika pada umur produktif tersebut tidak didukung dengan lingkungan kerja yang kondusif akan menurunkan motivasi perawat dalam bekerja. Perawat menjadi jenuh dan melakukan kegiatan asuhan keperawatan secara rutinitas akibatnya kemampuan kerja perawat menurun dan pengambilan keputusan klinik keperawatan yang dilakukan juga tidak berdasarkan standar yang ada.

2. Pendidikan, sertifikat, dan pelatihan

Selain usia faktor pendidikan juga berperan dalam hal pengambilan keputusan. Data ini menunjukkan bahwa pendidikan yang tinggi atau rendah tentu akan berpengaruh bagi seseorang untuk mengambil keputusan. Faktor sertifikat yang dimiliki oleh perawat juga seharusnya memiliki hubungan dalam hal perawat mengambil keputusan. Dengan adanya sertifikat pelatihan yang dimiliki perawat menunjukkan perawat tersebut kompeten berada di area perawatan kritis. Sertifikat yang dimiliki perawat sebagai kompetensi yang dimilki perawat tidak ternilai harganya, karena kompetensi ini akan mendukung perawat dalam mengambil keputusan independen dalam lingkungan perawatan kritis. Kompetensi yang diharapkan dapat berupa sertifikasi tingkat lanjut seperti advanced cardiac life supports, sertifikat klinik tingkat nasional dan keikutsertaan dalam suatu unit medis atau organisasi lain yang sejenis. Hasil penelian menunjukkan bahwa perawat yang ngkat pendidikan S1 keperawatan lebih banyak yang melakukan pengambilan keputusan dengan baik (60\%) dibandingkan perawat yang pendidikan DIII keperawatan. Hasil penelian menunjukkan bahwa perawat yang memiliki serfikat emergency dan non emergency melakukan 
pengambilan keputusan dengan baik $(69,7 \%)$ dibandingkan perawat yang dak memiliki serfikat (33,3\%). Pelahan merupakan upaya untuk mengembangkan kemampuan staf. Pelahan merupakan bagian dari proses pendidikan yang tujuannya meningkatkan kemampuan dan keterampilan khusus seseorang atau sekelompok orang. Dengan adanya pelahan diharapkan dapat meningkatkan kemampuan staf dalam hal pengetahuan, keterampilan dan sikap dalam bekerja (Notoatmodjo,2010). Adanya serikat yang dimiliki perawat memberikan gambaran bahwa perawat tersebut kompeten dan memiliki pengetahuan yang baik di bidangnya sehingga perawat terampil dan mempunyai skill yang baik untuk memberikan perawatan kepada pasiennya sehingga kualitas asuhan keperawatan yang diberikan

\section{Lama berkerja}

Lama kerja adalah jumlah tahun yang dilalui perawat selama bekerja di unit kerjanya sebagai perawat. Menurut Sinaga (2001) dalam Kurniadi (2013) semakin lama seseorang bekerja akan semakin terampil dan berpengalaman menghadapi masalah dalam pekerjaannya. Penelian oleh Hoffman, Duffield \& Donoghue (2005) didapatkan bahwa ada hubungan antara lama kerja dengan pengambilan keputusan. lama kerja akan membuat dan mempengaruhi seorang perawat dalam membuat keputusan. Oleh karena itu pengalaman sebelumnya pada sebuah kasus akan membantu ngkat keberhasilan dari situasi klinis serupa dimasa yang datang selain itu masa kerja yang cukup lama memungkinkan perawat untuk memiliki pengalaman kerja dan pengetahuan yang cukup sehingga mampu menghadapi tantangan beban kerja yang bervariasi. Faktor lama kerja perawat di unit dan unit tempat perawat bekerja akan mempengaruhi kemampuan dalam membuat keputusan. Hal ini tentu saja akan membuat perawat sudah terampil dan terbiasa dengan mengambil keputusan karena pengalaman sebelumnya pada sebuah kasus akan membantu tingkat keberhasilan dari situasi klinis serupa dimasa yang datang. Pelaksanaan pengambilan keputusan oleh perawat pada unit ini merupakan hal yang sangat penting sekali mengingat instalasi perawatan intensif merawat pasien - pasien kritis yang mendapatkan perawatan intensif sehingga jika perawat tidak cepat dalam pengambilan keputusan klinik maka akan menimbulkan kerugian bagi pasien yang seharusnya bisa ditangani dengan cepat dan tepat. Faktor lama kerja berhubungan dengan senioritas arnya semakin lama seseorang bekerja semakin lebih berpengalaman sehingga produkvitas kerja lebih meningkat. Masa kerja $>5$ tahun telah cukup lama menjalankan profesinya sebagai perawat karena semakin lama seseorang bekerja semakin banyak kasus yang ditanganinya sehingga meningkat pengalaman serta memberikan keahlian dan keterampilan kerja. (Supratman, 2008). Orang yang punya pengalaman akan selalu lebih pandai dalam menyikapi dari segala hal dari pada mereka yang sama sekali dak memiliki 
pengalaman (Gibson ,2009). awat yang memiliki pengalaman yang baik akan memberikan kemudahan dalam mengambil keputusan klinis terutama pada pengambilan keputusan klinis yang rumit. Faktor lama kerja perawat di IPI menjadi faktor yang paling dominan berhubungan dengan pengambilan keputusan klinik yang dilakukan oleh perawat. Semakin lama bekerja di unit kerja semakin membuat perawat terampil, pengetahuan meningkat tentang perawatan pasien dalam kondisi kris sehingga bisa lebih professional dalam bekerja dan kualitas asuhan keperawatan yang diberikan kepada pasien juga akan baik karena didukung oleh pengambilan keputusan klinik keperawatan yang baik pula.

\section{Sistem Pendukung dalam pembuatan keputusan perawat}

Berdasarkan penelitian yang dilakukan oleh Daniel Dady dkk dalam jurnalnya yang berjudul "sistim pendukung dalam pembuatan keputusan klinis perawat di ruang rawat inap :literatur review" menunjukkan terdapat 6 artikel yang membahas terkait sistim pendukung keputusan klinis yang digunakan perawat dalam membuat keputusan klinis di rumah sakit dengan konteks yang berbeda. Hal ini disebabkan karena peneliti ingin menampilkan secara menyeluruh terkait bagaimana sistim pendukung keputusan klinis dikembangkan, diukur akurasinya dan melihat yang sudah diimplementasikan serta kendala yang dihadapi pada saat penerapan sistim pendukung keputusan klinis tersebut sehingga dapat memberikan gambaran dalam mengadopsi sistim pendukung keputusan klinis bagi perawat di rumah sakit.

Kelebihan maupun kelemahan dari keenam artikel tersebut antara lain artikel yang membahas pengembangan CDSS untuk mengurangi kejadian kesalahan administrasi obat oleh perawat jika diterapkan akan sangat membantu perawat untuk memberikan obat secara aman kepada pasien. kelebihannya yaitu memberikan panduan yang baik bagi perawat onkology dalam membuat keputusan untuk perawatan pasien kanker akan tetapi kelemahannya adalah populasi yang digunakan terlalu kecil dan perlu diuji coba kepada populasi perawat yang lebih besar. Selanjutnya artikel tentang mengevaluasi efek dari penerapan metode refleksi Tanner pada pengambilan keputusan klinis perawat di ruangan ICU memiliki kelebihan yaitu ada evaluasi yang dilakukan untuk menilai sistim tersebut danartikel tentang evaluasi terhadap pengalaman perawat dalam menggunakan National Early Warning Score (NEWS) di rumah sakit akut. kelebihannya adalah bahwa dengan menilai pengalaman pengguna NEWS maka akan terlihat hal yang perlu diperbaharui dalam sistim itu serta studi untuk menggali hambatan menggunakan sistim pendukung keputusan klinis memiliki kelebihan untuk mengetahui hambatan dari pengguna sistim pendukung 
keputusan klinis. Pengembangan alat sebagi sistim informasi klinis pemberian obat dengan cara perawat diamati saat memberikan obat dalam lingkungan simulasi kemudian perawat berpartisipasi dalam kelompok fokus untuk memberikan masukan dan hasilnya perawat menunjukan kecenderungan untuk meremehkan kebutuhan akan dukungan(Moss \& Berner, 2015).

Hal ini sama dengan kenyatan didalam pelayanan pasien bahwa perawat tidak menggunakan sistim pendukung keputusan klinis untuk membuat keputusan pemberian obat yang aman juga ditunjukan dengan hasil penelitian bahwa 93\%perawat menerapkan kepatuhan keamanan obat dengan tidak tepat(Rohayani, 2018).Sistim ini masih dalam tahap pengembangan dan perlu dilakukan uji coba secara berulang untuk dapat diterapkan dalam pelayanan keperawatan di Indonesia. Pengembangan CDSS untuk perawat onkologyyang dilakukan dengan diuji coba kepada pasien dengan kanker selanjutnya menggali persepsi perawat yang menggunakan sistim tersebut.namun penggunaan CDSS pada perawat onkology, mereka menyatakan tidak mengalami masalah selama implementasi CDSS, dan penggunaannya memfasilitasi penilaian kebutuhan pasien dan manajemen perawatan (Ozdemir, 2015). Dalam perawatan pasien kanker belum digunakan CDSS untuk menilai kebutuhan pasien namun terlihat perilaku caring dari perawat terhadap pasien dengan kanker, hal ini didukung dengan hasil penelitian bahwa ada hubungan yang bermakna antara perilaku caringperawat dengan keyakinan dan harapan pasien(Sulisno \& Sari Pratika, 2014). Untuk dapat digunakan dalam perawatan pasien kanker di Indonesia maka perlu dilakukan terus uji coba penggunaan sistim ini sehingga memenuhi standar yang aman untuk pasien.

Dalam menilai akurasi diagnostik sistim pendukung keputusan klinis pada pasien dengan sepsis dilakukan dengan dua tahap yaitu dukungan keputusan klinis berbasis cloud untuk mendeteksi pasien yang berisiko mengalami sepsis, sistim cloud menyampaikan pemberitahuan kepada perawat yang ditunjuk pasien yang secara elektronik menghubungi penyedia layanan. Kedua terdiri dari skrining sepsis dan formulir stratifikasi yang diintegrasikan ke dalam catatan kesehatan elektronik pasien, yang merupakan alat bantu pengambilan keputusan berbasis bukti, yang digunakan untuk menilai pasien di samping tempat tidur dan hasilnya bahwa sistim alarm biner pendukung keputusan klinis dengan fungsionalitas cross-checking meningkatkan pengenalan dini dan memfasilitasi stratifikasi pasien dengan sepsis(Amland, Lyons, Greene, \& Haley, 2015). Dalam perawatan pasien sepsis di Indonesia belum digunakan sistim pendukung keputusan klinis oleh perawat dan 
hasil penelitian menunjukan mortalitas pasien sepsis dewasa akibat pneumonia di ICU masih tinggi(Lily, 2016).

Setiap sistim pendukung keputusan klinis yangakan digunakan harus dilakukan penilaian akurasi dari sistim tersebut sehingga pada saat digunakan, sistim tersebut dapat memberikan manfaat kepada pasien dan perawat serta rumah sakit sesuai dengan harapan. Demikian pula untuk menilai hambatan menggunakan sistim pendukung keputusan klinisdengan cara melakukan kelompok fokus bagi mereka yang merupakan pengguna akhir dari sistim pendukung keputusan EBMeDS yang terkomputerisasi dan hasilnya menunjukan bahwa hambatan paling penting untuk mendapatkan manfaat dari CDSS adalah kurangnya dokumentasi diagnosis terstruktur dan berkode serta informasi pengobatan yang ketinggalan zaman dalam catatan kesehatan elektronik(Koskela, Sandström, Mäkinen, \& Liira, 2016). Penilaian hambatan penggunaan sistim pendukung keputusan klinis oleh perawat belum dapat dilakukan karena terkait dengan belum digunakannya sistim pendukung keputusan klinis oleh perawat di rumah sakit.

Hambatan selalu ditemukan pada saat mengadopsi sistim yang baru, untuk itu apabila akan mengadopsi sebuah sistim pendukung keputusan klinis maka pihak manajemen harus terlebih dahulu mensosialisasikan sistim tersebut kepada para pengguna dan diajarkan cara penggunaannya. Evaluasi terhadap efek dari penerapan metode refleksi Tanner hasilnya menunjukan bahwa penerapan metode refleksi Tanner dapat secara signifikan meningkatkan skor rata-rata dan tingkat pengambilan keputusan klinis perawat ICU(Razieh, Somayeh, \& Fariba, 2018)dan evaluasi terhadap pengalaman perawat dalam menggunakan National Early Warning Score (NEWS)hasilnya yaitu perawat melaporkan bahwa NEWS mudah digunakan, tidak menambah beban kerja dan meningkatkan kemampuan perawat untuk mengidentifikasi pasien yang memburuk(Fox, 2015). Dalam perawatan pasien di rumah sakit termasuk di ruangan ICU belum digunakan sistim pendukung keputusan klinis bagi perawat. Kedua sistim ini meskipun sudah digunakan oleh rumah sakit di negara lain namun apabila akan diadopsi penggunaannya di rumah sakit di Indonesia maka harus dipelajari dulu manfaat dan kekurangannya sebelum digunakan sehingga pada saat digunakan dapat mendukung keputusan klinis yang dibuat oleh perawat dan tidak merugikan pasien dan rumah sakit.

\section{PENUTUP}

Sistim pendukung keputusan klinis (CDSS) yang dapat digunakan untuk mendukung keputusan klinis perawat adalah NEWS dan metode refleksi Tanner akan tetapi harus terlebih 
dahulu diuji coba dan disosialisasikan terkait manfaat serta cara penggunaannya kepada perawat, harus aman bagi pasien dan tidak merugikan pasien serta rumah sakit. Evaluasi terhadap efek dari penerapan metode refleksi Tanner hasilnya menunjukan bahwa penerapan metode refleksi Tanner dapat secara signifikan meningkatkan skor rata-rata dan tingkat pengambilan keputusan klinis perawat ICU(Razieh, Somayeh, \& Fariba, 2018)dan evaluasi terhadap pengalaman perawat dalam menggunakan National Early Warning Score (NEWS)hasilnya yaitu perawat melaporkan bahwa NEWS mudah digunakan, tidak menambah beban kerja dan meningkatkan kemampuan perawat untuk mengidentifikasi pasien yang memburuk(Fox, 2015). Dalam perawatan pasien di rumah sakit termasuk di ruangan ICU belum digunakan sistim pendukung keputusan klinis bagi perawat. Kedua sistim ini meskipun sudah digunakan oleh rumah sakit di negara lain namun apabila akan diadopsi penggunaannya di rumah sakit di Indonesia maka harus dipelajari dulu manfaat dan kekurangannya sebelum digunakan sehingga pada saat digunakan dapat mendukung keputusan klinis yang dibuat oleh perawat dan tidak merugikan pasien dan rumah sakit.

\section{DAFTAR PUSTAKA}

Christensen, P.J., \& Kenney, J.W. (2009). Proses Keperawatan, Aplikasi Model Konseptual (Terj. dari Nursing Process: Aplicaon of Conceptual Models. 4 th Ed). Jakarta: Penerbit Buku Kedokteran EGC.

Dady, Daniel., Erika, Kadek Ayu., \& Rachmawati, Rini. (2020). sistim pendukung dalam pembuatan keputusan klinis perawat di ruang rawat inap :literatur review. Jurnal Ilmu Kesehatan Vol. 8 No. 2

Erianti, Susi., Machmud, Rizanda., \& Harmawati. (2019). Determinan Pengambilan Keputusan Klinik Keperawatan di RSUD Arifin Achmad Provinsi Riau. Jurnal kesehatan komunitas. Vol. 5 No. 3

Ibrahim, Nur Kahfi., \& Winiarti, Sri. (2014). SISTEM PENDUKUNG KEPUTUSAN KLINIS UNTUK MENGEFISIENKAN DIAGNOSA PENYAKIT KEJIWAAN MENGGUNAKAN CASE BASED REASONING. Jurnal Sarjana Teknik Informatika Volume 2 Nomor 2

Latifah, Elfi. Laila. (2017). Sistem Pendukung Keputusan Klinis Untuk Memprediksi Kejadian Asfiksia Neonatorum. Elinvo (Electronics, Informatics, and Vocational Education), Vol. 2 No. 2 
Rosmalia, L., \& Kusumadewi, S. (2018). Sistem Pendukung Keputusan Klinis Untuk Menentukan Jenis Gangguan Psikologi Pada Pasien Gagal Ginjal Kronis ( GGK ) Yang Menjalani Terapi Hemodialisa. Jurnal Informatika Upgris (JIU), Vol. 4 No. 1

Simamora, R. H. (2019). Menjadi perawat yang: CIH'HUY. Surakarta: Kekata Publisher.

Simamora, R. H. (2005). Hubungan Persepsi Perawat Pelaksana Terhadap Penerapan Fungsi Pengorganisasian Yang Dilakukan Oleh Kepala Ruangan Dengan Kinerjanya Diruang Rawat Inap RSUD Koja Jakarta Utara (Doctoral dissertation, Tesis FIK UI, Tidak dipublikasikan).

Sri wahyuningsih. (2013). Kepercayaan dan pengambilan keputusan terhadap kinerja perawat. 2nd Internaonal Seminar on Quality and Affordable Educaon (ISQAE 2013)

Suharyanto, S., \& Asdie, Rizka Humardewayanti. (2015). Sistem Pendukung Pengambilan Keputusan Klinis Dalam Pemberian Terapi Antibiotik Yang Rasional. Simetris: Jurnal Teknik Mesin, Elektro Dan Ilmu Komputer, Vol. 6 No. 1

Sumijatun. (2009). Manajemen keperawatan konsep dasar dan aplikasi pengambilan keputusan klinis. Jakarta: CV Trans Info Media

Syaukani, M. (2018). Pemodelan Sistem Pendukung Keputusan Kelompok Klinis Sebagai Alat Bantu Diagnosis Pasien ISPA. Universitas Gadjah Mada 